\title{
Soil chemical properties of suboptimal dryland in subdistricts of Panji, Kendit, and Kapongan Situbondo Regency for development of cassava (Manihot utilissima L.) cultivation
}

\author{
Hylda Permata Riantara ${ }^{1}$ and Marga Mandala ${ }^{2}$ \\ ${ }^{1}$ Study Program of Agrotechnology, Faculty of Agriculture, University of Jember \\ ${ }^{2}$ Soil Science Study Program, Faculty of Agriculture, University of Jember \\ Jl. Kalimantan 37, Kampus Tegal Boto, Jember 68121
}

\begin{abstract}
Cassava has an important role as a potential caloric source for the community. Cassava has been known as a plant with wide range adaptability, thus it is very potential to be cultivated in areas with highly variated agro-ecological conditions such as temperate regions, marginal land, and dryland. This research aimed to study the chemical properties of suboptimal dryland in Panji, Kendit and Kapongan Subdistrict, Situbondo Regency for the development of cassava cultivation. The research was carried out by doing surveys and taking soil samples of suboptimal dryland in Subdistricts of Panji, Kendit, and Kapongan. Each subdistrict had 5 locations chosen as site obtaining soil samples. The soil samples were taken at a depth of $20 \mathrm{~cm}$, each soil sample was put into a plastic clip, then was labeled and brought to the Soil Fertility Laboratory for analysis of soil chemical properties. The soil chemical properties analyzed were $\mathrm{pH} \mathrm{H}_{2} \mathrm{O}$, cation exchange capacity (CEC), organic carbon, total Nitrogen, available Phosphate, and available Kalium. The results showed that the organic carbon, total Nitrogen, and available Phosphate became a limiting factor which belonged to the category of very low to low, with organic carbon of 0.80 $1.44 \%$, total Nitrogen of $0.12-0.17 \%$ and available Phosphate of 15.21 $15.97 \mathrm{ppm}$. Nevertheless, the soil chemical properties of suboptimal dryland are quite suitable for cassava, however other inputs are needed to the soil by fertilizing the organic matter, Nitrogen, and Phosphate.
\end{abstract}

Keywords: Cassava, Chemical properties, Dryland, Suboptimal.

\section{ARTICLE INFO}

Corresponding Author:

Hylda Permata Riantara

hylda.riantara43@gmail.com

Received: January 5, 2020

Accepted: May 15, 2020

Published: June 10, 2020

DOI: $10.19184 /$ jtiard.v1i1.16405

How to cite:

Riantara HP, M Mandala. (2020). Soil

chemical properties of suboptimal dryland in subdistricts of Panji, Kendit, and Kapongan

Situbondo Regency for development of cassava (Manihot utilissima L.) cultivation. J. Trop. Ind. Agric. Rural Dev. 1(1): 1-7

\section{INTRODUCTION}

The increased number of Indonesian populations is directly in line with the increased food demands. The national food uniformity carried out by the government leads to the intensified crop cultivation activities with only one agroecosystem, which is fields. Conversion of the function of fields into settlements and industries can threaten food security, thus endangering state sovereignty. The results of intensification efforts are not proportional to the high amount of food that is needed, therefore there is an urgent need for food extensification and diversification. Extensification efforts can be done by optimizing and empowering suboptimal dry land while diversification is done by cultivating alternative crops such as cassava. 
Cassava is a plant that has the great ability to produce tubers, therefore cassava will absorb lots of nutrients from the soil. Thus, the soil remains fertile and cassava productivity remains high, nutrients taken from the soil must be returned by fertilizing. The amount of fertilizer utilized depends on the state of the soil, the history of land use, the cultivar used, planting density, and so on. Unlike other commodities, cassava does not spawn a high quantity of nitrogen fertilizer. Excessive fertilization of nitrogen can inhibit the development of tubers and increase the content of cyanide acid. Soil nutrient which is pretty much needed by cassava plants is potassium. This compound functions in the formation of tubers (Prihandana and Hendroko, 2007).

The potency of suboptimal dry land utilization in East Java, particularly in the Situbondo Regency is still quite extensive but has not been utilized optimally for cassava cultivation. Situbondo Regency has an area of dryland in Kendit and Kapongan Subdistricts covering an area of 2,944 ha, Kendit Subdistrict covering 2,011 ha, and Kapongan Subdistrict covering an area of 933 ha. Current uses of suboptimal upland include rice, corn, chili, and peanuts. Data from the Central Statistics Agency of East Java (2017) shows the productivity of cassava plants in Situbondo Regency is still relatively low at 20 tons/ha. Cassava plant productivity has not been able to reach the production target of 40-60 tons/ha, therefore the use of suboptimal dry land for cassava plant development can increase the yield of cassava plant productivity to meet the needs of national cassava plants.

To increase the productivity of cassava plants, the soil chemical properties are very necessary, thus the nutritional needs of cassava plants can be fulfilled optimally. Data on the chemical properties of suboptimal dryland soils in Situbondo Regency are not yet available, therefore data on the chemical properties of soils is needed in the development of cassava plants in the suboptimal drylands. Based on this information, this research aimed to study the chemical properties of suboptimal dry land in the Subdistricts of Panji, Kendit, and Kapongan in Situbondo Regency for the development of cassava cultivation.

\section{MATERIAL AND METHOD}

This research was conducted from March to May 2019 in three subdistricts namely Panji,
Kendit, and Kapongan, Situbondo. Soil chemical analysis was carried out at the Soil Fertility Laboratory, Soil Science Study Program, Faculty of Agriculture, University of Jember. The equipment used for field survey was the Global Positioning System (GPS) in determining the sampling point of the soil; soil sampling tools such as shovels, knives, and plastic clips. Types of equipment used for chemical analysis in the Soil Fertility Laboratory were $\mathrm{pH}$ meters, Atomic Absorption and Spectrophotometer (AAS), distillation devices, and others. The materials used in this study were a sample of disturbed soil taken at each sample point, chemicals for chemical analysis of soil, and aquadest. Fields used as sampling location was dryland that has not been optimally utilized in the cultivation of food crops.

A sampling of disturbed soil was carried out with a scope and a knife at a depth of $20 \mathrm{~cm}$. Furthermore, soil samples were put into plastic clips, labeled, and then taken to the Soil Fertility Laboratory for soil chemical analysis assessment. Soil chemical analysis using samples of wind-dried soils that had been thoroughly being divided using 10 mesh $(2 \mathrm{~mm})$ sieve. Soil chemical analysis includes $\mathrm{pH} \mathrm{H}_{2} \mathrm{O}(\mathrm{pH}$ meter, $10 \mathrm{~g}$ of soil with $25 \mathrm{ml}$ aquadest), C-organic (Curmis method), CEC $\left(\mathrm{NH}_{4} \mathrm{Oac}\right.$ extract $1 \mathrm{M}, \mathrm{pH}$ 7), $\mathrm{N}$ total (Kjeldahl method), $\mathrm{P}$ available (Olsen method) and $\mathrm{K}$ available (Atomic Absorption and Spectrophotometer method).

\section{RESULT DAN DISCUSSION}

\section{$\mathrm{H}_{2} \mathrm{O} \mathbf{p H}$}

The $\mathrm{H}_{2} \mathrm{O} \mathrm{pH}$ value of soil in the subdistricts of Panji, Kendit, and Kapongan ranged from 6.34 to 6.88 belonged to the slightly acidic to neutral category. The soil $\mathrm{H}_{2} \mathrm{O}$ pH of Kendit subdistrict showed that the soil $\mathrm{H} 2 \mathrm{O} \mathrm{pH}$ value was lower than the soil $\mathrm{H}_{2} \mathrm{O} \quad \mathrm{pH}$ of Panji and Kapongan subdistricts. The $\mathrm{pH}$ value of $\mathrm{H}_{2} \mathrm{O}$ in Kendit subdistrict (Figure 1) was 6.34 classified as the slightly acidic category. High or low $\mathrm{pH}$ value of $\mathrm{H}_{2} \mathrm{O}$ is influenced by many factors, one of them is the type of soil. The sampling point at Kendit subdistrict has Alluvial and Mediterranean soil types or Inceptisol and Alfisol which generally have acidity to neutral $\mathrm{H}_{2} \mathrm{O} \mathrm{pH}$ values (Sutanto, 2005). The $\mathrm{pH}$ value of $\mathrm{H}_{2} \mathrm{O} 6.34-6.88$ is included in the very appropriate category because cassava plants can grow well with soil $\mathrm{pH}$ between 4.5 - 8.0 (Saleh et al., 2011). 


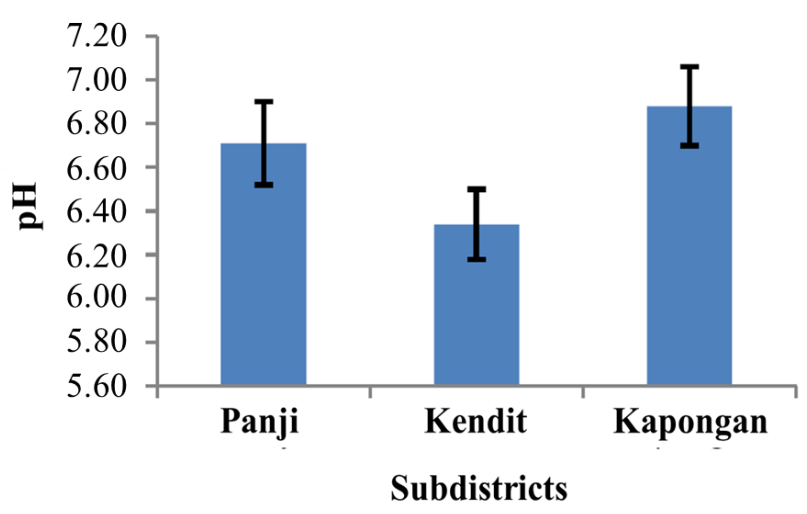

Figure 1. Soil $\mathrm{H}_{2} \mathrm{O}$ pH of Panji, Kendit and, Kapongan Subdistrics

Likewise, according to Ritung et al. (2011) cassava plants can grow well at $\mathrm{H}_{2} \mathrm{O}$ pH of 5.7-7. Therefore, soil in Panji, Kendit and Kapongan Subdistrict has a $\mathrm{pH}$ value that follow the requirements for growing cassava plants.

\section{C - organic}

Soil C-organic levels in the subdistricts of Panji, Kendit, and Kapongan ranged from 0.80-1.44\% belonged to in the very low to low category. Soil Corganic content in Panji Subdistrict showed that the C-organic value was lower than Kendit and Kapongan Subdistricts. The level of C-organic (Figure 2) in the Panji Subdistrict was $0.80 \%$ which was very low. High or low levels of soil Corganic is influenced by many factors, one of which is soil type. The soil types at the sampling point Panji Subdistrict are Grumusol, Litosol, and Regosol or Vertisol and Entisol which generally have very low to low C-organic content (Sutanto, 2005).

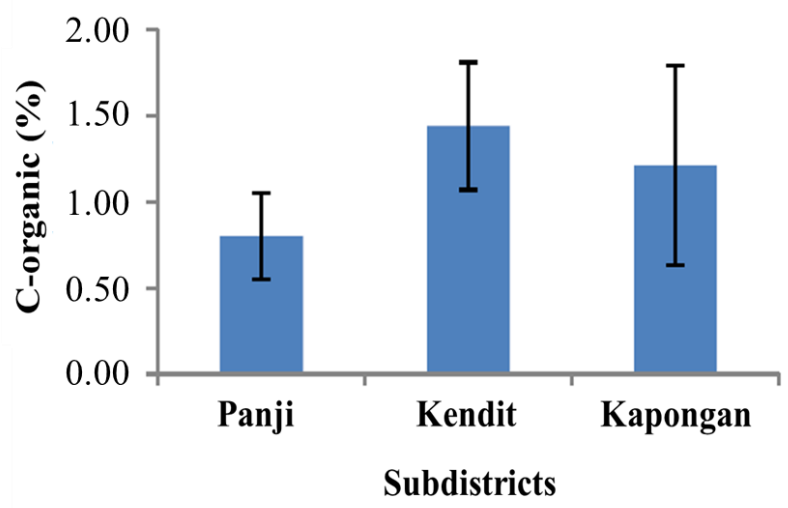

Figure 2. C-organic values of Panji, Kendit and Kapongan Subdistricts
C-organic content of $0.80-1.44 \%$ belonged sufficient category toward very suitable because cassava plants can grow well with $\mathrm{C}$-organic content of 1.2-3.0\% (Ritung et al., 2011). Therefore, the soil in Panji Subdistrict has C-organic content which is quite suitable for the growing requirements of cassava plants. Whereas Corganic content at Kendit and Kapongan Subdistricts were very suitable for cassava growing requirements. Similarly, according to Saleh et al. (2011) cassava plants can grow well with 2-4\% C-organic content.

\section{Cation exchange capacity}

The cation exchange capacity in the subdistricts of Panji, Kendit, and Kapongan ranged from 14.00$18.32 \mathrm{me} / 100 \mathrm{~g}$ belonged to the low to moderate category. The capacity of the soil ion exchange in the Kapongan Subdistrict (Figure 3) was 14.00 me/100g which was in the low category. High and low Cation Exchange Capacity is influenced by many factors, one of which is the type of soil. The soil sampling point of Kapongan Subdistrict has Litosol and Regosol or Entisol soil types which generally have a low Cation Exchange Capacity (Sutanto, 2005).

Cation Exchange Capacity of 14.00-18.32 me / $100 \mathrm{~g}$ was categorized as sufficient to the very appropriate category because cassava plants can grow well with a cation exchange capacity of 17-24 me/100g. Therefore, the soil in Panji and Kendit Subdistricts has a very suitable cation exchange capacity value for the growth requirements of cassava plants. Whereas in Kapongan Subdistrict, the value of cation exchange capacity is quite suitable for the growth requirements of cassava plants (Ritung et al., 2011).

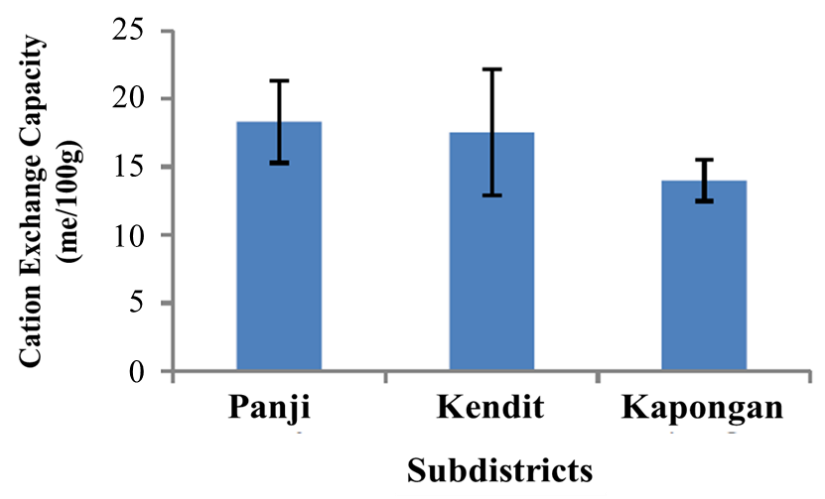

Figure 3. Cation exchange capacity of Panji, Kendit and Kapongan Subdistricts 


\section{Total Nitrogen (N)}

Total nitrogen $(\mathrm{N})$ in the subdistricts of Panji, Kendit, and Kapongan ranged between $0.12-0.17 \%$ belonged to the low category. Total soil nitrogen in Kendit Subdistrict is lower compared to Panji and Kapongan Subdistricts. The total $\mathrm{N}$ value in Kendit Subdistrict (Figure 4 ) is $0.12 \%$ as included in the low category. High and low total $\mathrm{N}$ is influenced by many factors, one of which is soil type. At the soil sampling point, Kendit Subdistrict has alluvial and regosol or inceptisol and entisol soil types which generally have low $\mathrm{N}$ content (Sutanto, 2005).

Total nitrogen $(\mathrm{N})$ of $0.12-0.17 \%$ belonged to the quite appropriate category because cassava plants can grow well with a total $\mathrm{N}$ of $0.21-0.50 \%$. Therefore, the fields at Panji, Kendit, and Kapongan Subdistricts have a sufficiently suitable value of total nitrogen as required for growing cassava (Ritung et al., 2011). Similarly, according to Saleh et al. (2011) cassava plants can grow well with the nitrogen content of $0.2 \%$.

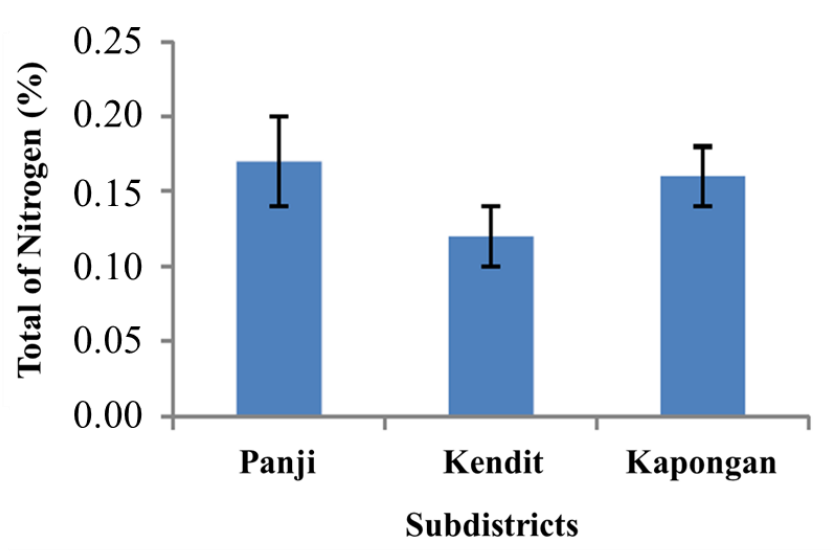

Figure 4. Total $\mathrm{N}$ values in Panji, Kendit and Kapongan Subdistricts

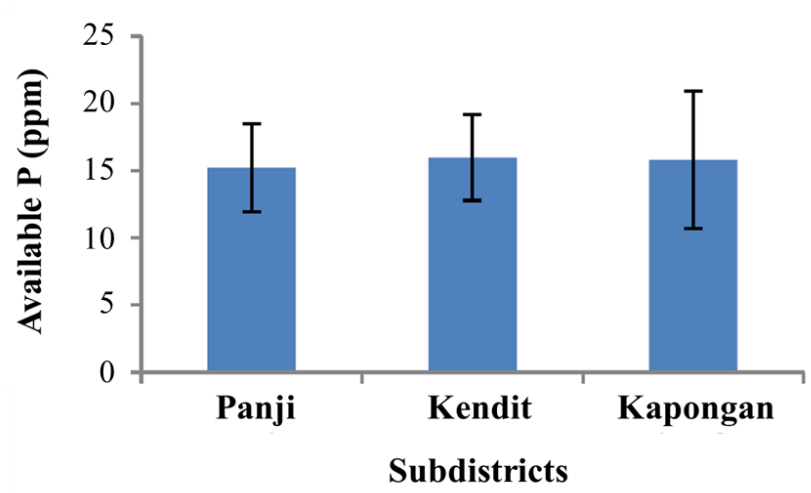

Figure 5. The value of available $\mathrm{P}$ in Panji, Kendit and Kapongan Subdistricts

\section{Available Phosphorus (P)}

Available $\mathrm{P}$ in the subdistricts of Panji, Kendit, and Kapongan was ranged from 15.21-15.97 ppm which was in the low category. The soil available Phosphorus (P) in Panji Subdistrict showed a lower value of available $\mathrm{P}$ compared to Kendit and Kapongan Subdistricts. The value of available $\mathrm{P}$ in Panji Subdistrict (Figure 5) was $15.21 \mathrm{ppm}$ belonged to the low category. High and low available $\mathrm{P}$ could be influenced by several factors, one of which is soil type. At the soil sampling point, Panji Subdistrict has Grumusol, Litosol, or vertisol and Entisol soil types which generally have low available P (Sutanto, 2005).

The available P levels of $15.21-15.97$ ppm were categorized as quite an appropriate category because cassava plants can grow well with available $\mathrm{P}$ content of $26-45 \mathrm{ppm}$. Therefore, the soil in the subdistricts of Panji, Kendit, and Kapongan is quite suitable for the growth requirements of cassava plants (Ritung et al, 2011). Similarly, according to Saleh et al (2011) cassava plants can grow well with low P-content of 4-15 ppm.

\section{Available Potassium (K)}

The available potassium $(\mathrm{K})$ in the subdistricts of Panji, Kendit, and Kapongan ranged from 0.84 - $3.18 \mathrm{me} / 100 \mathrm{~g}$ was in the high to very high categories. The soil available potassium $(\mathrm{K})$ in Kendit Subdistrict has a smaller available $\mathrm{K}$ value than Panji and Kapongan Subdistricts. The available K value of Kendit Subdistrict (Figure 6) was $0.84 \mathrm{me} / 100 \mathrm{~g}$ belonged to the high category. High and low of available $\mathrm{K}$ is influenced by several factors, one of them is soil type.

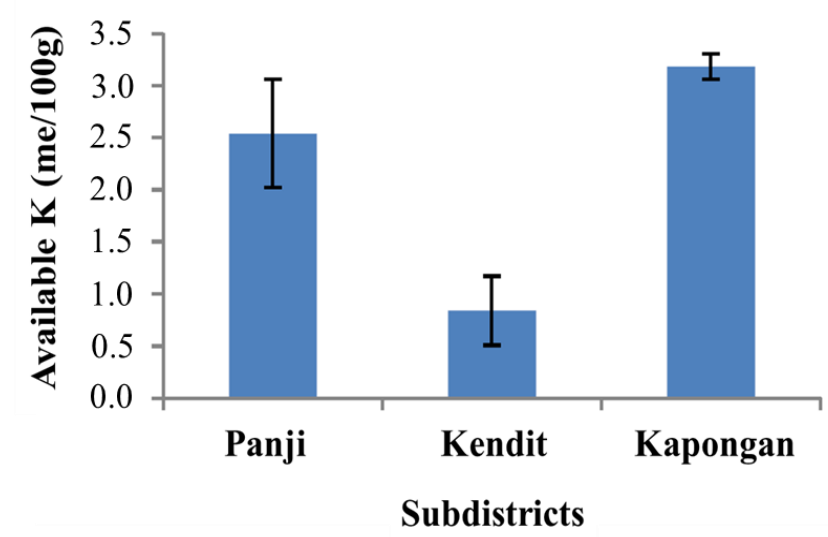

Figure 6. The value of available K in Panji, Kendit and Kapongan Subdistricts 
At the soil sampling point of Kendit Subdistrict has Alluvial and Regosol or Incepstisol and Entisol type soils that generally have low to moderate available K (Sutanto, 2005).

Available K content from 0.84 to $3.18 \mathrm{me} / 100 \mathrm{~g}$ belonged to the high to the very high category because cassava plants can grow well with the available $\mathrm{K}$ content of $0.4-0.5 \mathrm{me} / 100 \mathrm{~g}$. Therefore, the soils in the Panji, Kendit, and Kapongan Subdistricts have available $\mathrm{K}$ content which is very suitable for cassava growing requirements (Ritung et al., 2011). Similarly, according to Saleh et al. (2011) cassava plants require K nutrient content of 0,15-0,25 me/100g.

\section{Discussion}

Suboptimal dryland in the Panji, Kendit, and Kapongan Subdistricts, Situbondo Regency is used for planting corn and peanuts. In the irrigation method, the drylands rely on rainwater. Land management uses minimum tillage means without turning over the soil. There is no application for fertilizing dry land.

In general, the chemical characteristics of suboptimal dry land in the Panji Subdistrict for cassava growing requirements are quite appropriate. The limiting factors in Panji Subdistrict are C-organic content, total nitrogen content, and available phosphorus $(\mathrm{P})$ content. The results of soil chemical analysis in Kapongan Subdistrict for growth requirements of cassava plant showed a similar result which was also quite appropriate. The limiting factors in Kapongan Subdistrict were cation exchange capacity, total nitrogen and available P. Whereas soil chemical analysis in Kendit Subdistrict showed very suitable conditions. The limiting factors in Kendit Subdistrict were total nitrogen and available P. Thus, for the development of cassava cultivation in these three Subdistricts namely Panji, Kendit and Kapongan suboptimal dry land limiting factors were Corganic, $\mathrm{N}$ and $\mathrm{P}$. Determination of limiting factors is determined by soil fertility criteria with land requirements for cassava plants.

The results of the soil chemical analysis showed that the $\mathrm{pH}$ value of $\mathrm{H}_{2} \mathrm{O}$ in the subdistricts of Panji, Kendit, and Kapongan was included in the criteria of slightly sour to neutral. This criterion is very suitable for the land requirements of cassava cultivation, which are slightly acidic to neutral. The $\mathrm{pH}$ value affects the absorption of nutrients, if the $\mathrm{pH}$ is low will cause aluminum concentrations high enough so that it can inhibit growth. This is due to the inhibition of phosphate availability and the process of iron absorption which has an impact on poisoning in growth metabolism (Fahrudin, 2009). In general, plants easily absorb nutrients at a neutral $\mathrm{pH}$ because at that $\mathrm{pH}$ nutrients are more easily dissolved in water so that they can be absorbed by plants (Hardjowigeno, 1987).

The C-organic content in the Panji, Kendit, and Kapongan Subdistricts is very low to low based on land fertility assessment criteria. This criterion is sufficient based on the land requirements for cassava cultivation. The content of C-organic for the development of cassava cultivation in suboptimal dry land is very important because Corganic itself has an important role in providing nutrients, increasing acidic soil CEC, decreasing $\mathrm{P}$ fixation, helping to stabilize soil aggregates, modifying water retention and forming complexes with microelements. According to Supriyadi (2008), the very low C-organic content indicates that the potential of the soil to support agricultural production is less than optimal, due to the less ideal soil physicochemical conditions. Increasing the content of C-organic in the soil is a necessity so that the land is suitable for growing cassava plants.

The capacity of cation exchange found at Panji, Kendit and Kapongan Subdistricts belonged to the low-to-moderate category, this category was based on land fertility assessment criteria. This criterion ranged from sufficient to very suitable with the land requirements for cassava cultivation, Kendit Subdistrict had very suitable criteria. CEC has a very close relationship with soil fertility. Soil with high CEC can absorb and provide nutrients better compared with low CEC (Hardjowigeno, 1987). The ability of the cation exchange rate reflects soil fertility. The higher the CEC, the higher the ability of the soil absorption complex to bind cations. Cations which have an important role are $\mathrm{Ca}, \mathrm{Mg}$, $\mathrm{K}$, and $\mathrm{Na}$ as nutrients for plant growth and development. With the low CEC value, the ability of nutrient absorption is important for low plants (Martunis et al., 2017). An increase in CEC value is required, therefore suboptimal dry land in three districts is suitable for cassava cultivation.

The availability of $\mathrm{N}$ and $\mathrm{P}$ compounds is very important for the growth and development of cassava plants, especially in the suboptimal dry land. The $\mathrm{N}$ compound functions to arrange amino acids (proteins), nucleic acids, nucleotides, and chlorophyll in plants, while $\mathrm{P}$ compound functions 
as a storage and transfer of energy for the entire metabolic activities of plants. Low $\mathrm{N}$ values can lead to chlorosis, dwarf plants, imperfect fruit development results in drying fruit, low available $\mathrm{P}$ content can cause dwarf plants, underdeveloped root systems, purple leaves, inhibited flower/fruit /seed formation and the decrease of flowers percentage (Rani, 2015). Soil management needs to be done by providing some input into the soil, thus the $\mathrm{N}$ and $\mathrm{P}$ contents can be optimally available for cassava plant growth.

The available $\mathrm{K}$ content in those three subdistricts, namely the Panji, Kendit, and Kapongan belonged to high to a very high category based on the soil fertility assessment criteria. This criterion is very suitable for the land requirements for the development and cultivation of cassava. The $\mathrm{K}$ compound for cassava plants plays an important role in the formation and enlargement of tubers. If $\mathrm{K}$ deficiency occurs, it will affect the process of photosynthesis by plants, it can be due to old leaves which are supposed to work optimally to do photosynthesis are hampered due to young leaves taking the $\mathrm{K}$ element from these leaves. Therefore, the old leaves will begin to turn brownish-yellow which has the effect of inhibiting the process of photosynthesis (Hardjowigeno, 1987). If photosynthesis is obstructed, transport of photosynthesis results in the formation of cassava tubers can be inhibited.

The role of nutrients for the growth of cassava is fundamental. The availability of nutrients must be balanced; thus they can fulfill the productivity target of cassava plants. The results indicated that Panji, Kendit, and Kapongan Subdistricts had low nitrogen and phosphorus criteria. Therefore, it is a need for long-term efforts to minimize the potential deficiencies of Nitrogen and Phosphorus in the three subdistricts.

Cassava (Manihot utilissima L.) is known as a nutrient-hungry plant, it is based on one of the characteristics of cassava which is very efficient in absorbing nutrients (Radjit et al., 2014). However, the results of the study showed that C-organic, $\mathrm{N}$, and $\mathrm{P}$ in those three subdistricts were still low. To overcome these problems, several methods can be carried out, namely the provision of fertilizer directly either organic or inorganic materials. However, the continuous application of inorganic fertilizers will not provide a balance for the other elements.

The influence of excess inorganic fertilizers can cause a decrease in $\mathrm{pH}$ besides the provision of fertilizer on a sustainable basis can potentially change the structure physically, chemically, and biologically (Khairunisa, 2015). Chemically, organic matter is the main source of phosphorus and contributes a little nitrogen. Therefore, increasing the availability of nutrients can be performed by providing organic material, adding organic matter increases negative ions (cations) in the soil, therefore it can improve the status of soil CEC. Organic matter can also increase soil $\mathrm{pH}$, an increase in soil $\mathrm{pH}$ occurs due to an advanced decomposition in which the mineralized organic material releases minerals in the form of base cations (Atmojo, 2003). The provision of soil organic matter about 20 tons/ha (Shanti and Nirmala, 2018) can significantly influence the growth and yield of cassava.

\section{REFERENCES}

Atmojo SW. 2003. Peranan Bahan Organik Terhadap Kesuburan Tanah dan Upaya Pengelolaannya. Surakarta (ID): Sebelas Maret University Press.

Fahrudin F. 2009. Budidaya caisim (Brassica juncea L.) Menggunakan Ekstrak Teh dan Pupuk Kascing. [Skripsi] Solo (ID): Fakultas Pertanian. Universitas Sebelas Maret.

Hardjowigeno S. 1987. Ilmu Tanah. Jakarta (ID): Mediyatama Sarana Perkasa.

Khairunisa. 2015. Pengaruh Pemberian Pupuk Organik, Anorganik dan Kombinasinya Terhadap Pertumbuhan dan Hasil Sawi Hijau. [Skripsi] Malang (ID): Fakultas Pertanian. Universitas Islam Negeri.

Martunis, L., Sufardi, Muyassir. 2017. Pertukaran kation pada beberapa jenis tanah di lahan kering Kabupaten Aceh Besar Provinsi Aceh (Indonesia). [Prosiding] Banda Aceh: Seminar Nasional Pascasarjana. Universitas Syiah Kuala.

Prihandana R, R Hendroko. 2007. Bioethanol Ubi Kayu: Bahan bakar Masa Depan. Jakarta (ID) Agromedia Pustaka.

Radjit BS, Y. Widodo, N Saleh, N Prasetiaswati. 2014. Teknologi untuk meningkatkan produktivitas dan keuntungan ubikayu di lahan kering ultisol. IPTEK Tanaman Pangan 9(1): 51-62.

Rani D. 2015. Manfaat Unsur N, P, dan K Bagi Tanaman. Balai Penelitian Tanaman Pangan. Samarinda (ID): Badan Litbang Pertanian.

Ritung S, K Nugroho, A Mulyani, E Suryani. 2011. Petunjuk Teknis Lahan Untuk Komoditas Pertanian (Edisi Revisi). Bogor (ID): Balai Besar Penelitian dan Pengembangan sumberdaya Lahan Pertanian. Badan Penelitian dan Pengembangan Pertanian.

Saleh N, St A Rahayuningsih, MM Adie. 2011. Peningkatan Produksi dan Kualitas Umbi-Umbian. 
Malang (ID): Balai Penelitian Tanaman KacangKacangan dan Umbi-Umbian.

Shanti R, R Nirmala. 2018. Respon tiga varietas ubi kayu (Manihot esculenta L.) terhadap pemupukan di Kutai Timur. Jurnal Pertanian Terpadu 6(2): 46-58.
Supriyadi S. 2008. Kandungan bahan organik sebagai dasar pengelolaan tanah di lahan kering Madura. Embryo 5(2): 176-164.

Sutanto R. 2005. Dasar-Dasar Ilmu Tanah. Yogyakarta (ID): Kanisius. 